\title{
GIẢI PHÁP HUY ĐộNG VỐN TRÊN THỊ TRƯờnG TÀI CHÍNH QUỐC TẾ
}

\author{
NGUYẼN TRUNG TRỰC \\ Truờng Đại học Công nghiệp thành phố Hồ Chí Minh; \\ nguyentrungtruc@iuh.edu.vn
}

Tóm tắt. Hiện nay, trong xu hướng hội nhập kinh tế quốc tế, hội nhập thị trường tài chính, việc huy động vốn trên thị trường tài chính quốc tế là một tất yếu khách quan, nhằm tìm nguồn vốn với dung lượng thị trường lớn, chi phí sử dụng vốn thấp. Do đó, việc nghiên cứu giải pháp huy động vốn trên thị trường tài chính quốc tế cho các doanh nghiệp (DN) Việt Nam đầu tư trung và dài hạn là một nhu cầu cần thiết hiện nay. Đối tượng nghiên cứu là diễn biến lãi suất, tỷ giá VND/USD của Việt Nam và Hoa Kỳ từ năm năm 2009 đến 2016. Phương pháp nghiên cứu là phương pháp thống kê, phân tích nhằm tìm ra giải pháp huy động vốn với chi phí thấp, dung lượng đáp ứng yêu cầu đầu tư. Do đó nâng cao hiệu qủa hoạt động của các DN Việt Nam trong trong xu hướng hội nhập kinh tế quốc tế.

Từ khóa. Huy động vổn, thị trường tài chính quốc tế, thị trường trái phiếu, thị trường cổ phiếu, nhà đầu tư.

Abstract. Currently, in the trend of international economic and financial market integrations, and the mobilization of capitals in the international financial market are indispensable objectives to find capital with large market capacity and low capital cost. Therefore, researching solutions for Vietnam firms to raise capital in the international financial market for medium and long-term investments is a nowadays necessity. Research subjects are the movements of interest rate, and the VND / USD exchange rate of Vietnam and the US from 2009 to 2016. The statistical method is used to study, and to analyze to find solutions to mobilize capital with low spending cost, but enough capacity to meet investment requirements. Therefore, the efficiency of operations of Vietnamese enterprises is improved in the trend of international economic integration.

Keyworlds. capital mobilization, international financial market, bond market (capital market), stock market, investor.

\section{CƠ SỞ LÝ LUẬN}

\subsection{Huy động vốn trên thị truờng tài chính quốc tế}

Thị trường vốn quốc tế là nơi mua bán, chuyển giao các loại vốn có thời hạn trên một năm giữa những người cư trú và không cư trú. Đặc điểm của thị trường vốn quốc tế nhằm mục đích đầu tư phát triển trung và dài hạn. Tham gia vào thị trường vốn quốc tế là Chính phủ các nước, các công ty, các ngân hàng thương mại, các tổ chức quốc tế. Cấu trúc và hoạt động của thị trường vốn quốc tế bao gồm thị trường trái phiếu và thị trường cổ phiếu quốc tế. Hoạt động chính của thị trường vốn quốc tế ở tại các trung tâm tài chính quốc tế lớn trên thế giới, như New York (Hoa kỳ); Lon Don (Anh); Paris (Pháp); Tokyo (Nhật),... được hình thành từ việc quốc tế hóa thị trường vốn của một số nước có nền tài chính mạnh, hoặc một số nước có vị trí kinh tế chính trị đặc biệt.

\subsubsection{Thị truoòng trái phiếu quốc tế}

Thị trường trái phiếu quốc tế là nơi mua bán trái phiếu giữa các chủ thể cư trú và không cư trú, gồm có thị trường trái phiếu trong nuớc và nước ngoài. Đặc điểm của thị trường trái phiếu quốc tế là bổ sung nguồn lực tài chính trung và dài hạn, góp phần ổn định và thúc đẩy tăng trưởng kinh tế của các nước, nhất là của các $\mathrm{DN}$, đáp ứng khả năng thanh toán của các chủ thể khác nhau khi tham gia vào các hoạt động tài chính quốc tế, góp phần hình thành thị trường tài chính quốc tế.

Các chủ thể phát hành trái phiếu quốc tế là Chính phủ các nước, các cơ quan chức năng được ủy quyền. Chính quyền các địa phương hay liên bang, các tổ chức quốc tế: Ngân hàng thế giới (WB); Quỹ tiền tệ quốc tế (IMF); Ngân hàng Châu Âu (EIB), các doanh nghiệp và ngân hàng lớn: IBM; City Bank,...

Các chủ thể đầu tư trái phiếu quốc tế chủ yếu là khu vực tư nhân: Các cá nhân; Các doanh nghiệp; 
Các định chế tài chính, Ngân hàng trung ương hay Chính phủ các nước cũng tham gia đầu tư vào trái phiếu chính phủ các nước khác

Các công cụ trên thị trường trái phiếu quốc tế, căn cứ vào đặc điểm trái phiếu: Trái phiếu được đảm bảo; Trái phiếu chuyển đổi; Trái phiếu có lãi suất thả nổi.... Căn cứ vào thị trường (Đồng tiền ghi trên trái phiếu): Trái phiếu nước ngoài (global bonds); Trái phiếu Châu Âu (Eurobond), căn cứ vào thu nhập: Các công cụ nợ thu nhập cố định; Các công cụ nợ thu nhập thay đổi (lãi suất thả nổi)

Thị truoơng trái phiếu nuoớc ngoài: Là thị truờng mua bán trái phiếu do người không cư trú (Chính phủ, các công ty nuớc ngoài) phát hành tại một nước ghi bằng đồng tiền nước đó để thu hút vốn từ các nhà đầu tư nuớc ngoài. Thị trường chào bán công khai: Trái phiếu được đăng ký và giao dịch tại sở giao dịch chứng khoán phải thỏa mãn các điều kiện nhất định (chất lượng; tín nhiệm hay bảo lãnh,... ) là kênh rất quan trọng để cung cấp vốn trung và dài hạn cho các chủ thể không cư trú có nhu cầu sử dụng vốn đầu tư trung và dài hạn. Thị trường phi chính thức OTC (Over-The-Counter): Nhà phát hành trái phiếu không cần phải đăng ký với sở giao dịch và có thể bán trực tiếp cho nhà nhà đầu tư. Thông thường thị trường OTC có qui mô nhỏ và số lượng các nhà đầu tư tham gia ít.

Thị truờng trái phiếu Châu Âu là thị trường mua bán trái phiếu do người không cư trú (Công ty; ngân hàng; Chính phủ và các tổ chức quốc tế) phát hành nằm ngoài nước phát hành đồng tiền được ghi trên trái phiếu là dollar khi bán cho các nhà đầu tư Châu Âu; Châu Á,... (Ngoài Hoa Kỳ) và được ghi bằng EUR khi bán cho nhà đầu tư ở Hoa Kỳ... (Ngoài EU). Đây là thị trường trái phiếu quốc tế lớn nhất và phổ biến nhất trên thế giới và được phát hành ở nhiều trung tâm tài chính quốc tế và chủ yếu được ghi bằng đồng dollar. Chủ thể phát hành phải có hệ số tín nhiệm cao. Thời hạn dài, do đó, đây là kinh rất quan trọng để cung cấp nguồn vốn dài hạn cho các chủ thể phát hành.

Các công cụ là các trái phiếu có thể chuyển đổi; Trái phiếu lưỡng tệ; Trái phiếu tiền tệ đa quốc gia

Điều kiện tham gia vào thị trường trái phiếu: Đối với Chính phủ các nước phát triển, các tổ chức quốc tế, các ngân hàng và các công ty đa quốc gia lớn: Chủ thể phát hành phải có hệ số tín nhiệm cao, có khả năng quản lý và sử dụng vốn hiệu quả, có khả năng trả nợ. Chi phí phát hành và chi phí sử dụng vốn thấp, đồng thời phát huy được lợi thế của việc huy động vốn bằng phát hành trái phiếu. Đối với Chính phủ các nước đang phát triển, và các chủ thể phát hành chưa có uy tín lớn sẽ chịu chi phí phát hành lớn, ghi danh bằng ngoại tệ mạnh, khả năng sử dụng vốn kém, không thể tận dụng nợ luân chuyển, do đó, dễ mất khả năng thanh toán khi đáo hạn.

Lãi suất thực khi vay nợ ngoại tệ nước ngoài, $r_{f}$ được xác định bằng công thức:

Với: $\quad \mathrm{r}_{\mathrm{f}}$ : Lãi suất thực

$$
r_{f}=\frac{\left[\left(1+i_{f}\right) * \mathrm{~S}_{t+1}\right]-\mathrm{S}_{t}}{\mathrm{St}}=\frac{\left.\left(1+i_{f}\right) \mathrm{S}_{t+1}\right)}{\mathrm{St}}-1
$$

$i_{f}$ : Lãi vay ngoại tệ

$\mathrm{S}_{t}$ : Tỷ giá khi vay

$\mathrm{S}_{t+1}$ : Tỷ giá khi trả nợ

\subsubsection{Thị trường cổ phiếu quốc tế}

Thị trường cổ phiếu quốc tế là nơi mua bán cổ phiếu được phát hành bởi các công ty nước ngoài. Cần phân biệt "room" cho nhà đầu tư nước ngoài tại các sở giao dịch chứng khoán trong nước, nghĩa là nhà đầu tư nước ngoài được mua một tỷ lệ cổ phiếu nhất định của một DN trong nước. "Room" chỉ có giá trị trong nước, việc phát hành cổ phiếu ra nước ngoài thì không còn khống chế nữa. Cơ sở hình thành là Công ty nước này niêm yết ở sở giao dịch chứng khoán nước khác. Các công ty đa quốc gia có thể cùng một lúc niêm yết ở nhiều sở giao dịch chứng khoán ở các nước khác nhau. Sự hợp tác hay quốc tế hóa sở giao dịch cổ phiếu của một số nước đưa đến hình thành các trung tâm giao dịch lớn tài chính lớn: Euronext, Singapore, NYSE,...

Ưu thế khi tham gia thị trường cổ phiếu quốc tế: Tăng khả năng gọi vốn đầu tư cho các công ty ở các nước khác nhau, do đó tận dụng được lợi thế về cổ đông, về qui mô, về tỷ giá, đồng thời hạn chể rủi ro về chính trị, lãi suất, ... và đa dạng hóa quyền sở hữu, nâng cao vị thế và uy tín cho các công ty.

Các nghiệp vụ đầu tư cổ phiếu quốc tế: Bao gồm các nghiệp vụ đầu tư trên sở giao dịch chứng khoán, các nghiệp vụ đầu tư trên thị trường OTC. Chú ý cổ phiếu của cùng một công ty nhưng được mua bán tại các sở giao dịch khác nhau có thể khác nhau, do các yếu tố xác định giá trị và tỷ giá. Việc mua bán cổ phiếu tại các sở giao dịch tại các múi giờ khác nhau, do đó, giá của thị trường này sẽ là giá tham chiếu cho thị trường khác. 


\section{THỰC TẾ HUY ĐộNG VỐN TRÊN THỊ TRƯờnG TÀI CHÍNH QUỐC TẾ CỦA CÁC DN VIẸTT NAM.}

\subsection{Phát hành cổ phiếu ra thị trường tài chính quốc tế}

Vừa qua, chưa có $\mathrm{DN}$, NHTM Việt Nam nào trực tiếp phát hành cổ phiếu ra thị trường tài chính quốc tế mà chủ yếu bán cổ phiếu cho các doanh nghiệp, Ngân hàng thương mại nước ngoài mua lại tại thị trường tài chính Việt Nam, thông qua đầu tư gián tiếp. Cách tiếp cận này hiện được nhiều ngân hàng thực hiện khi huy động vốn trong nước gặp khó khăn. Điển hình là ngân hàng $\mathrm{ABBank}$ đã hai lần thành công với cách này và nhờ đó đã tăng vốn đáng kể. Năm 2008, ABBank đã thành công khi bán được $15 \%$ cổ phần của mình với mức giá gấp 5 lần mệnh giá cho Maybank - ngân hàng lớn nhất Malaysia, và thu về 2.138 tỷ đồng. Trong thời điểm khó khăn của các năm 2015; 2016, thành công này đã giúp ABBank có thêm nguồn lực để phát triển mạnh trong giai đoạn tiếp theo. Vừa qua, năm 2011, Maybank mua thêm $5 \%$ cổ phần để tiếp tục duy trì tỷ lệ sở hữu tối đa $20 \%$ của đối tác chiến lược nước ngoài. Ngoài ra $\mathrm{ABBank}$ còn còn thu hút thêm được 600 tỷ đồng từ công ty Tài chính quốc tế (IFC-International Finance Corporation) của Ngân hàng Thế giới WB (World Bank). IFC đầu tư để chính thức trở thành cổ đông với tỷ lệ sở hữu $10 \%$ vốn điều lệ. Với nguồn vốn từ nước ngoài, $\mathrm{ABBank}$ không chỉ tăng vốn thành công mà còn trở thành ngân hàng có tiềm lực tài chính mạnh trên thị trường.

Trong thời điểm khó khăn của nền kinh tế, thì quy định các ngân hàng phải tăng vốn điều lệ lên 3.000 tỷ đồng đã khiến cho nhiều ngân hàng thất bại, nhưng cũng có những ngân hàng đã thành công khi huy động được vốn nước ngoài

Trong số đó phải kể đển ngân hàng Phương Đông $(\mathrm{OCB})$ bán một phần vốn cho cổ đông nước ngoài là BNP Paribas (PNPP) để nâng tổng số vốn của mình từ 2.600 tỷ lên 3.000 tỷ đồng. Năm 2016, VIBank cũng được Ngân hàng Nhà nước chấp thuận tăng vốn điều lệ từ mức 4.000 tỷ đồng lên 4.250 tỷ đồng thông qua chào bán cổ phần cho Commonwealth Bank của Australia (CBA), với tỷ lệ sở hữu cổ phần CBA được nâng từ $15 \%$ lên $20 \%$. Mekong Bank cũng đã chào bán thêm cho đối tác chiến lược nước ngoài là Temasek Holdings Pte. Ltd (Singapore) $15 \%$ và dự tính sẽ nâng lên $20 \%$ trong năm 2014 để ngân hàng đạt vốn điều lệ 3.000 tỷ đồng.

\subsection{Phát hành trái phiếu ra thị truò̀ng tài chính quốc tế}

Hiện nay, trong việc huy động vốn trên thị trường trong nước đang gặp rất nhiều khó khăn - hạn mức tín dụng thấp; Lãi suất cao $(9 \% /$ năm); Khó vay; Việc huy động vốn khác, như phát hành cổ phiếu, trái phiếu, trên thị trường chứng khoán (TTCK) trong nước cũng trong hoàn cảnh tương tự... trong khi đó thì thị trường vốn nước ngoài không chỉ dồi dào mà còn có lãi suất rất hấp dẫn.

Việc phát hành trái phiếu, trái phiếu chuyển đổi trên thị trường quốc tế hiện nay khá thuận lợi, vì khuôn khổ pháp lý hiện hành đã tương đối hoàn thiện và đầy đủ (ngoài Nghị định số 14/2007/NĐ-CP quy định về hoạt động chào bán và niêm yết chứng khoán tại nước ngoài, trong năm 2011 , Chính phủ và NHNN đã ban hành Nghị định số 90/2011/NĐ-CP và Thông tư số 19/2011/TT-NHNN hướng dẫn phát hành trái phiếu DN ra nước ngoài và niêm yết chứng khoán của DN Việt Nam tại nước ngoài).

Hiện nay việc tìm nguồn vốn trên thị trường quốc tế không còn mới mẻ với nhiều doanh nghiệp (DN) Việt Nam. Trong 2 năm qua, huy động vốn từ thị trường quốc tế đã được các doanh nghiệp Việt Nam thực hiện khá thành công, đi đầu là Vincom khi năm 2009 tập đoàn này đã huy động được 100 triệu USD từ thị trường trái phiếu quốc tế. Bước sang năm 2011 mặc dù nền kinh tế thế giới vẫn đang đứng trước những thách thức không nhỏ nhưng tháng 7/2011 Vincom lại tiếp tục thành công lần thứ hai trong việc huy động thêm 40 triệu USD trái phiếu quốc tế với lãi suất $6 \%$ một năm (Lãi suất thực ở bảng 2.1 , có phí bảo lãnh). Số tiền thu được dùng để bổ sung vốn đầu tư trung và dài hạn cho Vincom. Đây là số tiền rất có ý nghĩa khi doanh nghiệp này đang cần nhiều vốn để thực hiện các dự án bất động sản (BĐS) lớn và các khoản đầu tư dài hạn khác. Nhờ nguồn vốn này mà các dự án của Vincom vẫn tiến hành đều đặn bất chấp những khó khăn của thị trường trong nước thời gian qua. 
Bảng 2.1: Bảng tính lãi suất thực - Trường hợp Vincom

\begin{tabular}{|c|c|c|c|c|c|c|c|}
\hline Năm & $\begin{array}{c}\text { Số vốn } \\
\text { huy động } \\
\text { (Triệu USD) }\end{array}$ & $\begin{array}{c}\text { Lãi suất } \\
\text { USD }\end{array}$ & $\begin{array}{l}\text { Tỷ giá } \\
\text { đầu năm }\end{array}$ & $\begin{array}{c}\text { Tỷ giá } \\
\text { cuối năm }\end{array}$ & $\begin{array}{l}\text { Lãi suất } \\
\text { thực }\end{array}$ & $\begin{array}{l}\text { Lãi suất } \\
\text { VND }\end{array}$ & $\begin{array}{l}\text { Chênh } \\
\text { lêch }\end{array}$ \\
\hline \multirow[t]{4}{*}{ Năm 2009} & 50 & $8,16 \%$ & 16.973 & 18.544 & $18,17 \%$ & $18 \%$ & $0,17 \%$ \\
\hline & 100 & $7,07 \%$ & 16.973 & 18.544 & $16,98 \%$ & $18 \%$ & $-1,02 \%$ \\
\hline & 150 & $6,71 \%$ & 16.973 & 18.544 & $16,59 \%$ & $18 \%$ & $-1,41 \%$ \\
\hline & 200 & $6,53 \%$ & 16.973 & 18.544 & $16,39 \%$ & $18 \%$ & $-1,61 \%$ \\
\hline \multirow[t]{4}{*}{ Năm 2010} & 50 & $8,16 \%$ & 18.544 & 18.932 & $10,43 \%$ & $12 \%$ & $-1,57 \%$ \\
\hline & 100 & $7,07 \%$ & 18.544 & 18.932 & $9,31 \%$ & $12 \%$ & $-2,69 \%$ \\
\hline & 150 & $6,71 \%$ & 18.544 & 18.932 & $8,94 \%$ & $12 \%$ & $-3,06 \%$ \\
\hline & 200 & $6,53 \%$ & 18.544 & 18.932 & $8,76 \%$ & $12 \%$ & $-3,24 \%$ \\
\hline \multirow[t]{4}{*}{ Năm 2011} & 50 & $8,16 \%$ & 18.932 & 20.828 & $19,00 \%$ & $19 \%$ & $0,00 \%$ \\
\hline & 100 & $7,07 \%$ & 18.932 & 20.828 & $17,79 \%$ & $19 \%$ & $-1,21 \%$ \\
\hline & 150 & $6,71 \%$ & 18.932 & 20.828 & $17,40 \%$ & $19 \%$ & $-1,60 \%$ \\
\hline & 200 & $6,53 \%$ & 18.932 & 20.828 & $17,20 \%$ & $19 \%$ & $-1,80 \%$ \\
\hline \multirow[t]{4}{*}{ Năm 2012} & 50 & $8,16 \%$ & 20.828 & 20.815 & $8,10 \%$ & $14 \%$ & $-5,90 \%$ \\
\hline & 100 & $7,07 \%$ & 20.828 & 20.815 & $7,00 \%$ & $14 \%$ & $-7,00 \%$ \\
\hline & 150 & $6,71 \%$ & 20.828 & 20.815 & $6,64 \%$ & $14 \%$ & $-7,36 \%$ \\
\hline & 200 & $6,53 \%$ & 20.828 & 20.815 & $6,47 \%$ & $14 \%$ & $-7,53 \%$ \\
\hline \multirow[t]{3}{*}{ Năm 2013} & 50 & $8,16 \%$ & 20.815 & 21.085 & $9,57 \%$ & $12 \%$ & $-2,43 \%$ \\
\hline & 150 & $6,71 \%$ & 20.815 & 21.085 & $8,10 \%$ & $12 \%$ & $-3,90 \%$ \\
\hline & 200 & $6,53 \%$ & 20.815 & 21.085 & $7,91 \%$ & $12 \%$ & $-4,09 \%$ \\
\hline \multirow[t]{3}{*}{ Năm 2014} & 50 & $8,16 \%$ & 21.085 & 21.380 & $9,68 \%$ & $10 \%$ & $-0,32 \%$ \\
\hline & 150 & $6,71 \%$ & 21.085 & 21.380 & $8,20 \%$ & $10 \%$ & $-1,80 \%$ \\
\hline & 200 & $6,53 \%$ & 21.085 & 21.380 & $8,02 \%$ & $10 \%$ & $-1,98 \%$ \\
\hline \multirow[t]{3}{*}{ Năm 2015} & 50 & $8,16 \%$ & 21.380 & 22.450 & $13,58 \%$ & $9 \%$ & $4,58 \%$ \\
\hline & 150 & $6,71 \%$ & 21.380 & 22.450 & $12,05 \%$ & $9 \%$ & $3,05 \%$ \\
\hline & 200 & $6,53 \%$ & 21.380 & 22.450 & $11,86 \%$ & $9 \%$ & $2,86 \%$ \\
\hline \multirow[t]{3}{*}{ Năm 2016} & 50 & $8,16 \%$ & 22.450 & 22.720 & $9,46 \%$ & $9 \%$ & $0,46 \%$ \\
\hline & 150 & $6,71 \%$ & 22.450 & 22.720 & $7,99 \%$ & $9 \%$ & $-1,01 \%$ \\
\hline & 200 & $6,53 \%$ & 22.450 & 22.720 & $7,81 \%$ & $9 \%$ & $-1,19 \%$ \\
\hline
\end{tabular}

Nguồn: http://www.vietcombank.com.vn/ExchangeRates/default.aspx và kết quả tính toán của tác giả (Truy cập ngày 18-02-2017)

Ghi chú: Bảng 2.1 theo đơn vị đo lường của Pháp

Phí bảo lãnh 1 triệu USD.

Năm 2009, nếu Vincom vay 100 triệu USD, với lãi suất USD là 6\%/năm, phí bảo lãnh 1 triệu USD thì lãi vay USD năm 2009 là : $r_{U S D}=\frac{100 *(1+6 \%)}{(100-1)}-1=7,07 \%$

Áp dụng công thức 1.1 trên chúng ta có lãi suất thực là: 


$$
r_{f}=\frac{(1+7,07 \%) * 18.855}{16.973}-1=16,98 \%
$$

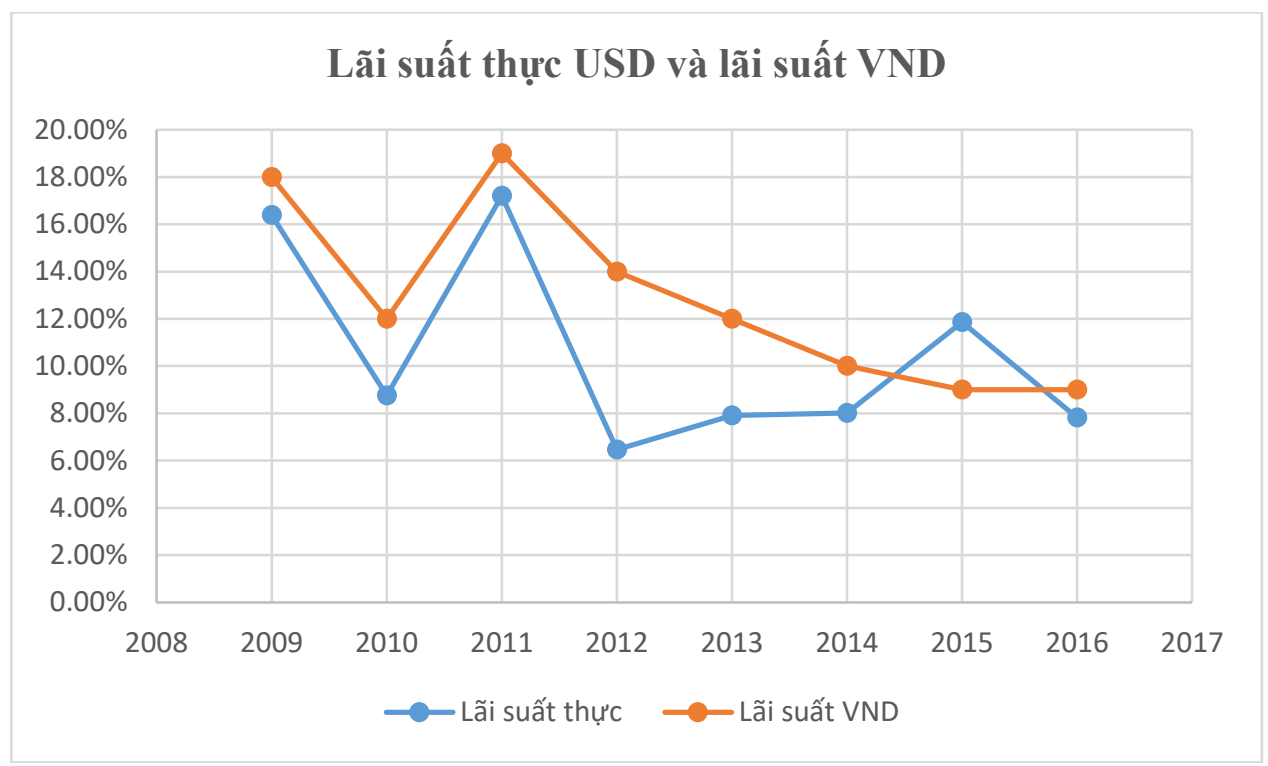

Hình 2.1: Đồ thị biểu diễn lãi suất thực USD và lãi suất VND.

Qua hai lần thành công, Vincom được xem là một trong những doanh nghiệp có kinh nghiệm nhất trong việc huy động vốn trên thị trường quốc tế, mở ra hướng mới cho các doanh nghiệp Việt Nam. Tiếp nối thành công của Vincom, tháng 5/2011, Hoàng Anh Gia Lai cũng đã huy động thành công 90 triệu USD trái phiếu quốc tế với thời hạn 5 năm; lãi suất theo USD ở mức cố định $9,875 \% /$ năm. Đây được xem là một thành công lớn của các doanh nghiệp trong nước khi doanh nghiệp này đã huy động được nguồn tài chính lớn trong hoàn cảnh khó khăn của thị trường tài chính thế giới.

Ngoài số vốn trên, từ cuối năm 2010, Hoàng Anh Gia Lai đã nhận định bối cảnh rất khó khăn nên đã tập trung mọi nguồn lực để huy động vốn. Cuối tháng 8/2010, Hoàng Anh Gia Lai đã huy động được 50 triệu USD từ tập đoàn Temasek, 60 triệu USD của Deutsche Bank.... đến cuối năm 2010 Hoàng Anh Gia Lai đã huy động thêm 55 triệu USD của Temasek, đây là những tổ chức tài chính lớn của thế giới.

Với kết quả trên, nhìn chung mặc dù nguồn vốn đầu tư cho các DN Việt Nam còn nhiều hạn chế, kênh huy động vốn trên thì trường tài chính quốc tế có nhiều ưu điểm, nhưng vẫn chưa được các doanh nghiệp Việt Nam và các ngân hàng thương mại trong nước khai thác có hiệu quả. Do hiện nay còn có sự khác biệt khá lớn giữa chuẩn mực kế toán Việt $\mathrm{Nam}$, (VAS) và chuẩn mực kế toán quốc tế (IAS), tính minh bạch báo cáo tài chính của $\mathrm{DN}$, NHTM Việt Nam chưa tốt và nhất là $\mathrm{DN}$ đa số ở qui mô vừa và nhỏ, hiệu quả hoạt động chưa cao,...

\section{GIẢI PHÁP HUY ĐỘNG VỐN TRÊN THỊ TRƯờnG TÀI CHÍNH TÀI CHÍNH QUỐC TẾ}

\subsection{Phát hành cổ phiếu và trái phiếu doanh nghiệp}

Để các doanh nghiệp Việt Nam có thể huy động vốn trên thị trường tài chính quốc tế, chúng ta cần giải quyết tốt một số trở ngại như sau:

\subsubsection{Giảm sụ khác biệt giữa chuẩn mục kế toán Việt Nam (VAS -Viet Nam Accounting Standards) và chuẩn mục kế toán quốc tế (IAS - International Accounting Standards).}

Trong xu hướng hội nhập kinh tế quốc tế để thuận lợi trong việc huy động vốn trên thị trường tài chính quốc tế và khu vực đề nghị Bộ Tài chính nghiên cứu có lộ trình xây dựng và áp dụng chuẩn mức kế toán Việt Nam (VAS) tương đồng với chuẩn mực kế toán quốc tế (IAS), như cáo tài chính, nhất là báo cáo kết quả hoạt động kinh doanh rất rườm rà, nặng về quản lý thuế, chưa chú trọng quản trị tài chính, 
chưa tính được một số chỉ tiêu quan trọng về dòng tiền hoạt động $(\mathrm{OCF})$, trên báo cáo, tính số tiền khấu hao theo phương pháp đường thẳng còn khác biệt (loại trừ phế liệu khi kết túc dự án),... . Ngoài ra, các doanh nghiệp Việt Nam có thể áp dụng dụng hình thức niêm yết Chứng chỉ Lưu ký Toàn cầu (GDRGlobal Depositary Receipt) trên thị trường tài chính quốc tế và khu vực. Để làm được điều này Bộ Tài chính; Ngân hàng nhà nước Việt Nam và thị trường chứng khoán (TTCK) nơi DN dự định niêm yết chéo phải đạt được một số thỏa thuận liên quan đến đầu tư ra nước ngoài, quản lý ngoại hối, xử lý vấn đề chuyển đổi đối với đồng tiền Việt Nam khi chưa có khả năng chuyển đổi và thanh toán quốc tế...

\subsubsection{Nâng cao hiệu quả hoạt động}

Để đáp ứng những đòi hỏi khắc khe của TTCK ở các nước, nhất là thị trường chứng khoán Singapore (SGX), DN Việt Nam phải có lợi nhuận lũy kế trước thuế 3 năm liên tiếp đạt 7,5 triệu USD, trong đó, có ít nhất trên 1 triệu đô la/năm) và thị trường chứng khoán Hoa Kỳ NYSE (các DN quốc tế phải có tổng lợi nhuận trước thuế 3 năm gần nhất là 100 triệu USD, lợi nhuận trong 2 năm liên tiếp gần nhất là 100 triệu USD/năm) và NASDAQ Global Select (DN phải có tổng lợi nhuận 3 năm liên tiếp là 11 triệu USD, doanh thu năm liền kề trước năm phát hành 110 triệu USD...; Với sàn NASDAQ Global, DN phải có vốn cổ đông là 15 triệu USD hoặc 30 triệu USD, thu nhập trước thuế của năm liền kề trước đó hoặc trong 2 năm bất kỳ trong 3 năm gần nhất là 1 triệu USD). Do đó, điều kiện quan trọng nhất để được phát hành trái phiếu; cổ phiếu ở các thị trường tài chính quốc tế là $\mathrm{DN}$ phải kinh doanh có hiệu quả tương đối cao và qui mô DN lớn. Để thực hiện điều này đòi hỏi DN Việt Nam phải có đội ngũ quản trị điều hành chuyên nghiệp cao và trình độ công nghệ tương đối hiện đại, hoạt động trong những ngành; những lĩnh vực mà Việt Nam có lợi thế: Xuất khẩu gạo, cà phê, hạt điều, tiêu...Thủy sản, du lịch ...

\subsubsection{Tăng tính minh bạch thông tin}

Đối với các nhà đầu tư nước ngoài việc minh bạch hóa thông tin, nhất là thông tin về tài chính có vai trò rất quan trọng. Do đó các DN Việt Nam muốn huy động vốn trên thị truờng tài chính quốc tế cần phải thực hiện tốt yêu cầu này, nhất là yêuu cầu về tính chính xác, đúng hạn về thời gian.... Ngoài ra viêc lập báo cáo tài chính theo tiêu chuẩn kế toán Việt Nam (VAS), DN Việt Nam cần lập báo cáo tài chính theo chuẩn quốc tế (IFRS - International Financial Reporting Standards) để tăng thềm niềm tin cho nhà đầu nước ngoài. Do vậy, DN Việt Nam cần thuê công ty kiểm toán quốc tế có uy tín tư vấn tốt về dịch vụ này.

Ngoài ra chi phí cho việc phát hành trái phiếu và cổ phiếu tương đối cao, có thể lên đến 2 triệu USD bao gồm chi phí kiểm toán, tư vấn pháp luật và tư vấn doanh nghiệp... Đây là điều DN Việt Nam cần cân nhắc giữa lợi ích đạt được và chi phí bỏ ra, thông thường việc huy động vốn trên thị trường quốc tế chỉ dành cho những DN có qui mô lớn.

\subsubsection{Lãi suất thục thấp}

Với những kết quả phân tích trên, qua tính toán cho thấy lãi suất thực khi huy động đồng USD trên thị trường tài chính quốc tế khá thấp.

Nếu đầu năm 2016, DN Việt Nam cần phát hành trái phiếu trên thị trường quốc tế với số tiền 150 triệu USD, lãi suất $6,00 \%$ /năm, chi phí phát hành, bảo lãnh,... 1 triệu USD.

Lãi suất vay ngoại tệ thực tế (EAR-Effective Annual Interest Rates) một năm sẽ là:

$$
\mathrm{EAR}=\frac{150 *(1+6 \%)}{(150-1)}-1=6.71 \%
$$

Với công thức (1) : $\mathbf{r}_{\mathrm{f}}=\left(\mathbf{1}+\mathbf{i}_{\mathrm{f}}\right) \frac{\mathbf{S}_{\mathrm{t}+1}}{\mathbf{S}_{\mathrm{t}}}-\mathbf{1}$

$$
r_{f}=\frac{(1+6.71 \%) * 22.720}{22.450}-1=7,99 \%
$$

Kết quả lãi suất thực khi phát hành trái phiếu quốc tế ở bảng 2.1, với các mức vốn huy động khác nhau sẽ có lãi suất thực khác nhau.

Qua kết quả tính toán trên, cho thấy huy động vốn trên thị trường tài chính quốc tế với hình thức phát hành trái phiếu $\mathrm{DN}$, trong năm năm qua từ 2009 đến 31 tháng 12 năm 2016, có nhiều ưu điểm như lãi suất thực thấp; nguồn vốn lớn, nhất là đối với $\mathrm{DN}$ có qui mô vừa và lớn đây là một kênh quan trọng cho các DN xuất khẩu Việt Nam. 


\subsection{Phát hành chúng chỉ lưu ký toàn cầu GDR (Global Depositary Receipt)}

Chứng chỉ Lưu ký Toàn cầu (GDR) là loại chứng chỉ do một ngân hàng quốc tế phát hành, có tài sản cơ sở (Underlying asset) là cổ phiếu của một công ty nước ngoài. Vì vậy, GDR được xem là một sản phẩm phái sinh. Theo qui định khi phát hành và giao dịch ở một nước hay vùng lãnh thổ, thì tên nước hay lãnh thổ đó sẽ đứng trước DR thí dụ: Tại Hoa Kỳ là $\mathrm{ADR}$, châu Âu là EDR, Trung Quốc là CDR...

Huy động vốn GDR là hình thức huy động vốn quốc tế thông qua một ngân hàng lưu ký. Thay vì phát hành trực tiếp cổ phiếu ra thị trường quốc tế, doanh nghiệp phát hành sẽ lưu ký một lượng cổ phiếu tại ngân hàng lưu ký, sau đó ngân hàng này sẽ tiếp tục phát hành các chứng chỉ lưu ký trên cơ sở số lượng cổ phiếu đang nắm giữ cho các nhà đầu tư (NĐT) ở nước ngoài, (Sơ đồ 3.1). Các chứng chỉ này cũng sẽ được niêm yết trên thị trường thứ cấp và giao dịch như cổ phiếu; thông thường các nhà đầu tư tham gia là giới chuyên nghiệp.

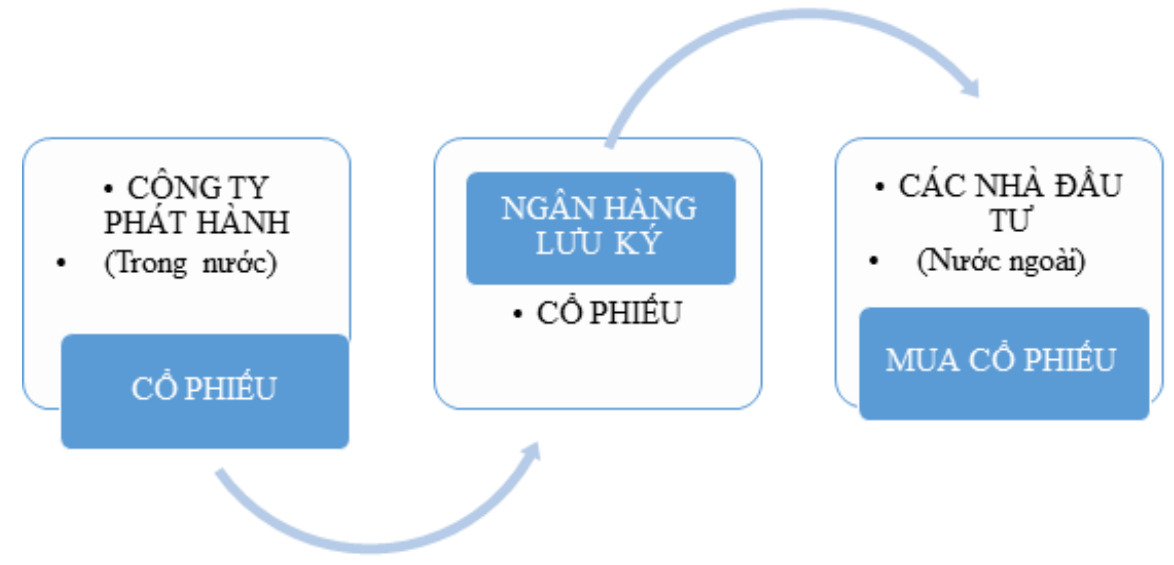

Sơ đồ 3.1: Sơ đồ phát hành cổ phiếu ra nước ngoài

\section{(1) Lọi ích đối với nhà đầu tư (NĐT)}

Với GDR sẽ mang lại rất nhiều lợi ích cho nhà đầu tư như sau:

- Đực thục hiện giao dịch trong nước đối với một sản phẩm đầu tư nước ngoài. Điều này giúp họ không phải chuyển đổi ngoại hối vì ngân hàng lưu ký trung gian đã thực hiện thay cho giao dịch này. Ngoài ra, NĐT cũng được thực hiện giao dịch với hệ thống thanh toán, lưu kí quen thuộc cũ trước đây, không cần phải làm quen với hệ thống giao dịch mới của nước ngoài. Một lợi ích khác, NĐT sẽ nhận được các thông tin về doanh nghiệp bằng ngôn ngữ của chính nước mình, không cần mất nhiều thời gian nghiên cứu thông tin bằng tiếng nước ngoài.

- GDR giúp NĐT tránh đực các quy định về hạn chế nắm giñu cổ phiếu nước ngoài. Thông thường Chính phủ các nước đều qui định một tỷ lệ cổ phiếu mà nhà đầu tư nước ngoài được phép nắm giữ tối đa nhưng với GDR giúp họ tránh được sự hạn chế này.

- Đối với Sponsored GDR, các nhà đầu tư có quyền lợi nhu một người nắm giũ cổ phiếu phổ thông (quyền nhận cổ tức, quyền tham dự và biểu quyết tại ĐHCĐ). Điểm khác biệt duy nhất là họ không được trực tiếp thực hiện các quyền (rights) mua cổ phiếu cơ sở. Thay vào đó, các quyền mua này sẽ được ngân hàng lưu ký bán đi và trả tiền cho NĐT.

- NĐT được tự do chuyển nhượng GDR trên sàn giao dịch chúng khoán mà GDR đang niêm yết hoạc sử dụng quyền chọn bán lại cho ngân hàng luu ký để nhận lại cổ phiếu ở sàn trong nước. Điều này giúp tăng tính linh hoạt cho NĐT.

- Giảm chi phí đầu tu: Khi phát hành GDR, tổ chức phát hành (TCPH) hay nhà đầu tư không phải trả phí lưu ký ở nước ngoài, thông thường ở mức từ 10 đến 35 điểm cơ bản một năm nếu cổ phần được mua bán trực tiếp trên sở giao dịch chứng khoán (SGDCK) nước ngoài. Mặt khác nhà đầu tư còn tránh được khoản thuế ở nước sở tại hay thuế chuyển nhượng thường được đánh vào các giao dịch mua bán cổ phần trực tiếp.

- Tính thanh khoản cao: GDR có mức thanh khoản cao do việc cung ứng và nhu cầu có thể được điều chỉnh thông qua việc tạo thêm hay hủy bỏ các phần GDR mà nhà đầu tư đang nắm giữ.

(2) Lợi ích đối với doanh nghiệp

- GDR là một kênh huy động vốn có hiệu quả, trong bối cảnh lãi suất trong nước cao, thị trường 
chứng khoán suy thoái. Đặc biệt GDR không đòi hỏi nhiều thủ tục rườm ra và không bắt buộc DN phải tuân thủ các qui định sau niêm yết như báo cáo tài chính; luật quản trị công ty.... Thuận lợi khác của GDR là dễ dàng giao dịch, thanh toán cổ tức theo đồng tiền mua GDR, thường là dollar, và các thông báo, công bố thông tin cho các nhà đầu tư hoặc tài liệu đại hội đồng cổ đông, thực hiện quyền của cổ đông đều được thể hiện bằng tiếng Anh.

- Mặt khác việc niêm yết GDR trên sàn giao dịch nước ngoài sẽ giúp tăng tính minh bạch và quảng bá thương hiệu của $\mathrm{DN}$ Việt Nam với nhà đầu tư nước ngoài. Do đó, GDR là một kênh huy động vốn phù hợp với DN Việt Nam hiện nay.

(3) Cơ chế hoạt động của thị trưòng giao dịch GDR

Tương tự sản phẩm phái sinh, DR (Depositary receipts) có thể được tạo ra hoặc hủy bỏ phụ thuộc vào cung cầu thị trường. Khi công ty phát hành thêm cổ phần mới, sẽ có thêm cổ phiếu giao dịch trên thị trường và lưu ký tại Ngân hàng lưu ký (NHLK), trên tài khoản của Ngân hàng thanh toán (NHTT). Kế tiếp NHTT sẽ phát hành GDR cho các nhà đầu tư. Việc tạo thêm hay hủy bỏ các cổ phần tín thác sẽ làm cho giá của cổ phần tín thác theo sát giá cổ phiếu của doanh nghiệp vì mọi sự khác biệt sẽ được xóa bỏ hoàn toàn thông qua việc đầu cơ vào GDR của các nhà đầu tư.

Lúc đầu giá của GDR tùy thuộc vào tỷ lệ tín thác (gọi là tỷ lệ DR). Tỷ lệ tín thác là số lượng các GDR đại diện cho cổ phần cơ sở với khung giá biến động rộng, tùy thuộc cách định giá GDR trong mối liên hệ tương quan với giá cổ phần cơ sở. Một GDR có thể đại diện cho quyền sở hữu của một số cổ phần công ty hoặc một tỷ lệ cổ phần nào đó, tùy thuộc vào việc GDR được định giá cao hơn hay thấp hơn cổ phần của công ty.

Đa số các GDR đều được định giá theo giá thị trường, do đó, nó có lợi thế cạnh tranh với cổ phần của công ty nếu cả hai được giao dịch trên cùng một SGDCK. Thường một GDR được định giá dao động trong khoảng từ 7USD đến 20USD. Nếu giá GDR thay đổi vượt ra khỏi khoảng giá tối ưu trên thì sẽ có nhiều GDR được phát hành hoặc tất toán làm cho giá GDR quay lại khoảng giá tối ưu trên, điều này được NHTT xác định. Vì vậy, về phía thị trường có thể thấy nếu nhu cầu đầu tư GDR tăng lên thì sẽ có nhiều GDR được phát hành và ngược lại, hoặc giá của cổ phiếu cơ sở công ty sẽ tăng lên tương ứng.

Các nhân tố ảnh hưởng đến giá của GDR cũng tương tự như đối với cổ phiếu công ty: các thông tin cơ bản về tình hình hoạt động của công ty, các báo cáo tài chính, giá trị doanh nghiệp, các phân tích và khuyến cáo của chuyên gia; điều kiện thị trường....

Việc giao dịch GDR ở các sở GDCK trên thế giới cũng tương tự như giao dịch cổ phiếu, cũng có cơ chế thanh toán $\mathrm{T}+3$. Công ty sẽ là người lựa chọn sàn giao dịch cho GDR. Hiện tại có các sàn giao dịch GDR như sau: Sàn GDCK London, Luxembourg, Singapore, Hongkong.... Thông thường các công ty chọn sàn GDCK cho GDR dựa vào nhận định rằng khi GDR của họ được giao dịch trên Sàn giao dịch nào thì các nhà đầu tư tại thị trường đó am hiểu nhiều nhất về công ty của họ và có nhà đầu tư nước ngoài lớn nhất. Hiện nay hầu hết các GDR được giao dịch tại Sàn GDCK London hay Luxembourg, do đây là những sàn giao dịch hàng đầu để niêm yết các GDR, chi phí niêm yết thấp hơn các sàn khác và mất ít thời gian hơn khi phát hành GDR.

NHTT Hoa kỳ phát hành GDR tuân thủ theo Quy chế S của Luật Chứng khoán Hoa kỳ năm 1933. Chứng chỉ GDR không được giao lại cho người nắm giữ GDR nhưng sẽ dựa vào chứng chỉ chính (Master Certificate) do Common Depository nắm giữ phục vụ mục đích thanh toán.

Tên của các $\mathrm{DR}$ nắm giữ theo tên giao dịch của ngân hàng hoặc môi giới tại tổ chức tín thác chứng khoán, như Depository Trust Company $(\mathrm{DTC})$, Euroclear hay Clearstream. Người nắm giữa $\mathrm{DR}$ hưởng lợi ích từ việc giao dịch cổ phần, cổ tức hay quyền biểu quyết.

Khi có kế hoạch phát hành GDR mới, chủ thể phát hành phải công khai thông báo trên thị trường rằng việc phát hành GDR có thể làm ảnh hưởng đến giá giao dịch của cổ phiếu cơ sở hay không?

(4) Qui trình phát hành chứng chỉ lưu ký toàn cầu (GDR)

Ngân hàng tín thác (NHTT) thay mặt cho tổ chức phát hành (TCPH) tiến hành phát hành và quản lý GDR. NHTT thường đặt trụ sở hoặc có chi nhánh tại các quốc gia có gia có giao dịch GDR. Những NHTT lớn nhất hiện nay ở Mỹ là JP Morgan, Bank of New York Mellon và Citibank.

NHTT và tổ chức phát hành GDR thỏa thuận xác định rõ nghĩa vụ và quyền lợi của mỗi bên, nghĩa vụ của cả hai bên đối với các nhà đầu tư hoặc bên thứ 3 . Những điều khoản thỏa thuận bao gồm không giới hạn nội dung ngày ghi sổ, quyền biểu quyết đối với cổ phần cơ sở, lưu ký cổ phần tại NHTT, chia sẻ phí, và việc thực hiện, phân phối các GDR cho nhà đầu tư. 
Ngân hàng lưu ký (NHLK) nắm giữ số lượng cổ phần của công ty phát hành dưới hình thức GDR. NHTT mua cổ phần của công ty phát hành và lưu ký cổ phần đó tại NHLK sau đó phát hành GDR đã mua dưới dạng quyền sở hữu cổ phần của công ty phát hành. Các DR được mua bán đó gọi là phần tín thác.

Cũng giống như NHTT ngân hàng lưu ký (NHLK) thường có trụ sở tại các quốc gia có TCPH đặt trụ sở và nắm giữ các cổ phần cơ sở dưới dạng GDR. Các NHTT thường chọn NHLK để thực hiện nghĩa vụ phân phối cổ tức trực tiếp cho các chủ sở hữu nắm giữ GDR.

Quyền biểu quyết trong hầu hết các thỏa thuận tín thác quy định rằng NHTT sẽ được quyền biểu quyết dựa trên cơ sở số lượng cổ phần cơ sở được quy ước bằng GDR do các nhà đầu tư nắm giữ và theo ý kiến biểu quyết của các nhà đầu tư. Nếu không có ý kiến của các nhà đầu tư đang nắm giữ GDR, NHTT không được biểu quyết.

\section{(5) Vai trò và trách nhiệm trong việc phát hành GDR}

Để phát hành GDR, trước tiên TCPH phải ký hợp đồng với các nhà tư vấn bao gồm các ngân hàng đầu tư, luật sư và kế toán. Kế tiếp TCPH cũng phải lựa chọn một NHTT để quản lý việc triển khai kế hoạch. NHTT đóng một vai trò rất quan trọng trong việc điều phối giữa các bên liên quan đến giao dịch và sẽ đảm bảo đầy đủ vai trò trong dài hạn khi triển khai phát hành GDR. Cụ thể:

- Môi giới: Chọn các GDR đáp ứng nhu cầu của nhà đầu tư.

- Ngân hàng tín thác:

+ Tư vấn cơ cấu phát hành GDR.

+ Chỉ định NHLK ở nước sở tại.

+ Thỏa thuận quản lý tài khoản với NHLK và các thủ tục liên quan.

+ Phối kết hợp với Luật sư và các ngân hàng đầu tư để triển khai các bước.

+ Chuẩn bị và phát hành GDR vào ngày đóng sổ.

+ Điều phối tiếp quá trình phát hành và hủy bỏ GDR.

+ Nghiên cứu quy trình thanh toán tại thị trường giao dịch GDR.

+ Tư vấn quan hệ với các nhà đầu tư.

- Ngân hàng lưu ký:

+ Là đại lý thị trường địa phương cho NHTT.

+ Nhận và giữ các tài khoản lưu giữ cổ phần cơ sở đối với việc phát hành GDR.

- Tổ chức phát hành:

+ Xây dựng kế hoạch tài chính và mục đích phát hành.

+ Hợp đồng với NHTT, ngân hàng đầu tư, luật sư và kế toán.

+ Xác định cơ cấu GDRs.

+ Cung cấp thông tin tài chính cho các ngân hàng đầu tư, luật sư.

+ Thực hiện quan hệ nhà đầu tư.

- Ngân hàng đầu tư:

+ Chủ trì quá trình bảo lãnh phát hành.

+ Thành lập tổ hợp các ngân hàng tham gia.

+ Tư vấn cơ cấu vốn.

+ Tư vấn cơ cấu phát hành GDR.

+ Xin cấp mã giao dịch cho chứng khoán phát hành.

+ Xin giấy phép đáp ứng tiêu chuẩn tín thác điện tử cho GDR.

+ Tham gia quá trình Roadshows.

+ Định giá và phát hành GDR.

- Luật sur:

+ Tư vấn các luật chứng khoán hiện hành và các luật lien quan.

+ Tư vấn cơ cấu phát hành GDR (liên quan đến luật pháp).

+ Đàm phán quản lý tài khoản.

+ Kiểm tra các tài liệu và các văn bản liên quan.

+ Chuẩn bị các thủ tục liên quan đến việc niêm yết giao dịch GDR.

+ Cho ý kiến về các vấn đề pháp lý.

- Kế toán:

+ Lập các báo cáo tài chính theo các tiêu chuẩn kế toán quốc tế.

+ Tồng hợp và chỉnh sửa bản công bố thông tin về các nội dung kế toán. 
Do đó, chúng ta có thể thấy rằng, các GDR là một công cụ giúp các công ty có thể huy động được vốn quốc tế một cách tiết kiệm về chi phí và thời gian. Đây cũng là cách nhanh nhất có thể giúp công ty tăng sự có mặt của mình tại thị trường chứng khoán vốn nước ngoài mà thông thường trước đây các $\mathrm{DN}$ phải thực hiện IPO quốc tế.

\subsection{Các NHTM Việt Nam huy động vốn trên thị truoòng tài chính quốc tế để cho các DN trong nước vay}

Các NHTM Việt Nam cần tham gia huy động vốn trên thị trường tài chính quốc tế để cho các DN trong nước vay trung dài hạn. Vì với kinh nghiệm chuyên môn và uy tín cao hơn $\mathrm{DN}$, các NHTM Việt Nam có lợi thế hơn khi phát hành cổ phiếu; trái phiếu và chứng chỉ lưu ký toàn cầu GDR (Global Depositary Receipt) trên thị trường tài chính quốc tế với chi phí thấp, lãi suất hấp dẫn và đây là điều kiện để cho vay với lãi suất cạnh tranh, tạo điều kiện cho các DN, cá nhân Việt Nam vay đầu tư hiện đại hóa công nghệ sản xuất, xuất khẩu.

\section{KẾT LUẬN}

Huy động vốn trên thị trường tài chính quốc tế với hình thức phát hành cổ phiếu; trái phiếu DN hay Phát hành chứng chỉ lưu ký toàn cầu GDR (Global Depositary Receipt) có nhiều ưu điểm như chi phí sử dụng vốn thấp, dung lượng nguồn vốn lớn, đây là một kênh huy động vốn ngoại có hiệu quả cho các DN Việt Nam, nhằm tạo điều kiện cho $\mathrm{DN}$ đầu tư hiện đại hóa công nghệ sản xuất, nâng cao khả năng cạnh tranh trên thị trường quốc tế, thực hiện thành công chiến lược công nghiệp hóa đất nước.

\section{TÀI LIỆU THAM KHẢO}

\section{Tài liệu nước ngoài}

01) Barry J. Epstein, EvaK. Jermakowicz, 2010, Interpretation and Application of International Financial Reporting Standards, Published by John Wiley \& Sons, Inc., Hoboken, New Jersey Published simultaneously in Canada

02) Eugene F. Brigham, Phillip R. Daves, 2016, Intermediate Financial Management, 12th Edition, Published by Cengage Learning

03) Eugene F. Brigham, Joel F. Houston, 2015, fundamentals of financial management Eighth Edition. Published by Cengage Learning

04) Jeff Madura, 2015. International Financial Management, 12th edition. Published by McGraw-Hill.

05) Jeff Madura, International Financial Management, 11th edition 2012, Published by Cengage Learning.

06) Stephen A. Ross, Randolph W. Westerfield and Jeffrey Jaffe, 2016. Corporation Finance 11e edition. Published by McGraw-Hill

07) Investments, Bodie; Kane, Marcus, tenth edition - McGraw Hill, 2014

\section{Tài liệu trong nước:}

01) Trần Ngọc Thơ và cộng sự, 2005. Tài chính doanh nghiệp hiện đại. Nhà xuất bản Thống kê.

02) Nguyễn Trung Trực, 2016, Giáo trình Tài chính doanh nghiệp 1, Nhà xuất bản kinh tế Tp HCM

\section{Web:}

1) http://data.imf.org/regular.aspx?key=60998127. Truy cập 08-01-2017

2) http://data.imf.org/regular.aspx?key=60998120. Truy cập 08-01-2017

3) http://data.imf.org/regular.aspx?key=60998125. Truy cập 09-01-2017

4) http://data.imf.org/regular.aspx ?key=60998122. Truy cập 09-01-2017

5) http://www.vietcombank.com.vn/ExchangeRates/default.aspx, Truy cập ngày 18-02-2017

Ngày nhận bài: 16/04/2017 Ngày chấp nhận đăng: 31/07/2017 